\title{
SOCIAL COLLATERAL MODEL FOR ISLAMIC MICROFINANCE
}

\author{
Amrizah Kamaluddin \\ Universiti Teknologi MARA, Shah Alam, Malaysia \\ Email: amrizah@salam.uitm.edu.my \\ Nabawiyah Abdul Hadi \\ Universiti Teknologi MARA, Shah Alam, Malaysia \\ Md. Mahmudul Alam \\ University Utara Malaysia, Malaysia \\ Email: rony000@gmail.com \\ Mohamed Azam Mohamed Adil \\ Universiti Teknologi MARA, Shah Alam, Malaysia
}

\section{Citation Reference:}

Kamaluddin, A., Hadi, N.A., Alam, M.M., and Adil, M.A.M. 2015. Social Collateral Model for Islamic Microfinance. Journal of Developing Areas. Vol. 49(5), pp. 353363. [Online Link]

This is a pre-publication copy.

The published article is copyrighted by the publisher of the journal. 


\title{
SOCIAL COLLATERAL MODEL FOR ISLAMIC MICROFINANCE
}

\begin{abstract}
This study examines the social collateral model for Islamic microfinance in Malaysia. Using qualitative instruments on academics and officers of microfinance institutions as the sample study, this study identifies the components that should be included in the social collateral model for Islamic microfinance. Based on interviews and focus group discussions, this study found that similar to the conventional microfinance, the Islamic microfinance also include social capital, group pressure, entrepreneurship skills, and culture as the components of social collateral model. In addition, this study found that religiosity represents another important component of the social collateral model for Islamic microfinance.
\end{abstract}

JEL Classifications: G21, I30, L31

Keywords: Social Collateral, Social Capital, Islamic Microfinance, Entrepreneurship, Religiosity, Malaysia

Corresponding Author's Email Address: amrizah@salam.uitm.edu.my

\section{INTRODUCTION}

Throughout the world, governments in developing countries have taken the initiatives to improve the lives of their people. One of the ways to improve the lives of their people is to reduce the economic gap between the rich and the poor. This is important as it does not only improve the quality lifestyle of the poor but also in achieving the status of a developed country. In assisting the poor, one of the initiatives that these governments have relied upon is microfinance. Microfinance has been receiving wide attention in the past few years because this mechanism is viewed as one of the most important sources in changing people's lifestyle especially the poor (United Nations World Summit Outcome Documents, 2005). This is evident as the General Assembly of United Nations has proclaimed the year of 2005 as the Year of Microcredit (Mahjabeen, 2008).

Microfinance was introduced to assist the poor in changing their lifestyle. This could be done by providing financial assistance to the poor so that they can use the funds to generate income and consequently, improve their lifestyle. Such assistance was given to the poor because of their inability to obtain financial assistance from the financial institutions. Assadi (2014) reported that in 2013, there were 2.455 billion people worldwide failed to access banking services due to their inability to provide collateral asset which is a common requirement of the banks before giving loan to their customers.

Microfinance uses group lending approach that offers allocation of loans to a group of people. The group lending approach relies on "social collateral" that allows the microfinance recipients to obtain financial services without physical collateral requirements (Conning, 1996; Hulme and Wright, 2006). It provides some assurances that the microfinance recipients who have little or no financial collateral would be able to repay the loan. Social collateral is created by forming a group of microfinance recipients so that these recipients may experience social pressure in repaying the loan. The recipients from the group are jointly liable for the loan repayment. In microfinance program, each member of the group must repay current borrowing in order to obtain future loans from the microfinance institutions. The members in the group are also expected to monitor and apply social pressure among them so that every member would be liable to repay the loans (Rotzer, 2007). 
Various definitions of social collateral have been provided in the literature. For example: CALA Social Capital, a UK-based social enterprise defined "social collateral" as no physical collateral to pledge against the loans (CALA, 2013). On the other hand, Siddiqi (2008) illustrated that social collateral serves as a substitute of material collateral. Conning (1996) opined that social collateral can be created through group lending approach in order to replace the missing of the physical collateral. The guarantee relies on the group members' responsibilities to repay the loan. If one of the group members defaults, then other members would be liable for the loan repayment. Dowla (2006) argued that the main purpose of organising the microfinance recipients into groups is to use peer pressure as a guarantee for the loan repayment and that all members would be jointly liable for the loan provided to them. Gine and Karlan (2010) also noted that joint liability often perform better than individual liability. The joint liability principal approach is created to ensure all group members become more liable for the group loan repayment. If one member defaults, then other group members may not able to take up the next loan until all loan repayments have been made (Brau and Woller, 2004).

Rinne (2012) argued that social collateral in microfinance requires group members to be responsible toward their loan repayment. Kumar (2012) found that social collateral plays a significant role in reinforcing repayment from the group members. Nugroho and O'Hara (2008) have provided two ways to encourage the group members to be responsible for their loan repayment. The first way is by creating punishment such as rumour and bad reputation for those who has made no attempt to repay the loan. The second way is through friendship that can strengthen the moral value of the microfinance recipients to repay the loans. Eberhard (2008) also highlighted the effectiveness of this approach to be dependent on the trustworthiness of the group members. Similarly, Besley and Coate (1995) suggested that imposing social penalty on the group members will improve the performance of group lending in terms of repayment rates. Higher repayment rates would lead to higher profitability of rural lending and therefore, improve availability of rural credit.

As an upper middle income country, Malaysia also adopts microfinance in assisting her nation. This is evidenced by Malaysia's modern financial system with a diverse range of institutions of both public and private institutions. As one of the modern financial systems, Islamic microfinance is becoming popular among the Malaysian financial institutions. It involves the provision of a broad range of financial services such as deposits, loans, payment services, money transfers, and insurance to poor and low-income households and their microenterprises. However, there is no evidence of a uniform social collateral model on microfinance among these institutions. Therefore, this study attempts to examine the social collateral model from the Islamic perspective based on Malaysian experience.

\section{METHODOLOGY}

This study uses interviews and focus group discussions as the research instruments. The research instruments were conducted on representatives comprising of local and international academics and officials from the Islamic microfinance institutions in Malaysia. Seven academics participated in the interview sessions. Two focus groups comprising of officials from the Islamic microfinance institutions were formed. These focus groups consist of 3 officials from Amanah Ikhtiar Malaysia (AIM) ${ }^{1}$ and 4 officers from Perbadanan Usahawan Malaysia Berhad (PUNB) ${ }^{2}$.

The focus group discussions and interviews were conducted to determine the components of social collateral model for Islamic microfinance. Upon completion of the 
focus group discussions and interviews, the qualitative data obtained from the interviews and focus group discussion were analysed and categorised into different constructs.

\section{FINDINGS AND DISCUSSION}

Based on the qualitative analysis of the interviews and focus group discussions, this study found that there are five components that should be incorporated in the social collateral model for the Islamic microfinance. The five components are social capital, group pressure, entrepreneurship skills, culture and religiosity as shown in Figure 1.

\section{FIGURE 1. SOCIAL COLLATERAL MODEL FOR ISLAMIC MICROFINANCE}

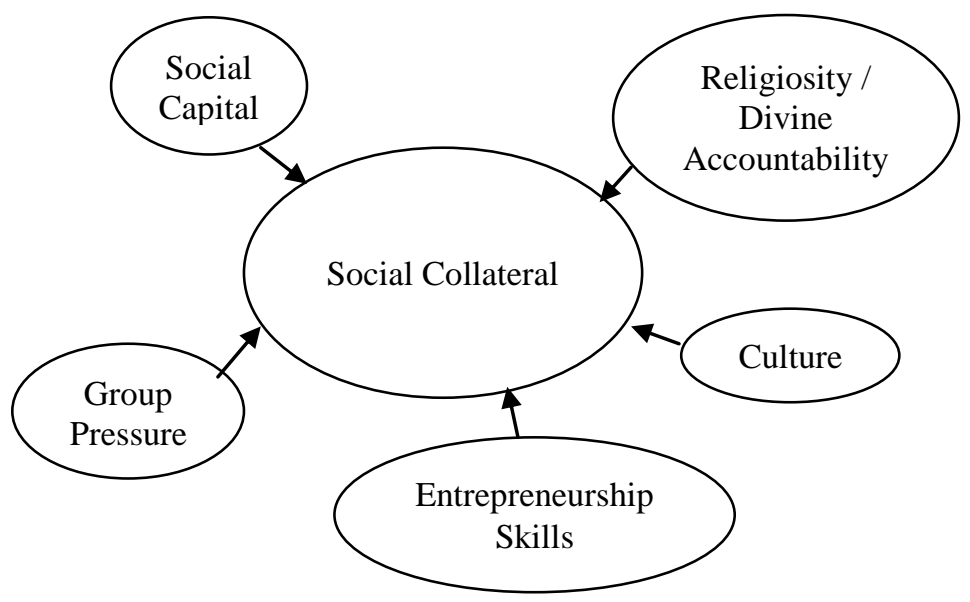

Source: Authors

\section{Social Capital}

This study found that social capital is an important component of Islamic microfinance. There are two sub-components of social capital namely, trust and networking. In referring to trust, the opinions of one of the participant is - "I believe that trust plays an important influencing factor among Islamic institutions. In normal circumstances, we normally identify the credibility of the borrowers by looking at their ability to pay. And their ability to pay can be indicated through previous record."

In referring to networking, the opinions of few of the participants are - "Networking is an important role in determining the success of micro-financing among Islamic financial institutions and often networking is reflected by politics among the individuals, institutions and society as a whole.", "The more connection that we have, the better the networking that we have and consequently, provide better access to the opportunities."

The participants in this study also mentioned on the importance of networking. They noted that "Networking is an important role in determining the success of micro-financing among Islamic financial institutions and often is reflected by politics among the individuals, institutions and society as a whole", "The more connection that we have, the better the networking that we have and consequently, provide better access to the opportunities." 
Previous studies have also considered social capital as an important component of social collateral model. These studies defined social capital as a process of communication and interaction within community that can establish and promote networks, trust, social obligations and practices (Putnam, 1993; Nughoro and O'Hara, 2008). Putnam (1993, p.167) in his study defined social capital as "networks, norms, and trust that facilitate cooperation for mutual benefit". World Bank (2009) also defined social capital as the norms and network that enables collective action and shapes quality and quantity of society's social interactions.

Trust refers to individual's feeling that can rely on the promise of other people (Nugroho and O'Hara, 2008). Consistent with Eldblom and Jarl (2012) trust is determined by fairness and helpfulness. Kropp, Turkey, Just, Kong and Guo (2009) found that microfinance institutions could be successful in providing loans to the poor people based on the basis of trust. Similarly, Cassar, Crowley and Wydick (2007) examined trust in South Africa and Armenia and found trust as an important factor in determining group loan and repayment performance. On the other hand, Putnam (1993, p.174) noted that "networks facilitate communication and improve the flow of information about the trustworthiness of individuals". Such finding indicated that more communication that exists among the group society would results in the enhancement of trust.

On the other hand, network is determined by associations, membership of organisations and people willingness to engage in the civic society (Nielson, 2012). Bryant and Norris (2002) indicated that network also includes contact with friends, family and neighbours and depth of socialisation network. This is consistent with the opinion of a participant who is currently attached to a public university. In a study performed by Karlan, Mobius, Rosenblat, and Szeidl (2009) on the network connections between individuals in the group to secure the informal borrowing, they found that the results signify networks having positive effect on borrowing. It confirms that networks are better in forming social collateral.

On the other hand, several studies have found that social capital in terms of networking have a positive relationship with performance of entrepreneurs. For example: Gomez and Santor (2001) found that social capital is more likely to enhance the economic performance of entrepreneurs through social interactions and network resources. It will protect relationship and improve welfare, encourage people to work together and easy to access information. These findings supported previous studies (Morris, Woodworth, and Hiatt, 2006; Woodworth, 2008; Molla and Alam, 2011; Alam and Molla, 2012) that claimed strong connectivity between the successful of microentrepreneurs and development of social capital especially social network. Similarly, Morris et al., (2006) examined the performance of small entrepreneurs in Bulgaria and Philippines between individual lending approach and group lending approach. They reported that group lending approach has led to going concern of the businesses and better performances. This is attributed by the existence of social capital in the organisations.

\section{Group Pressure}

The study also found that the group pressure as an important component of the social collateral model in the Islamic microfinance institutions. The participants in this study mentioned that group pressure reduces default problems. One of the statement on this issue was made by a participant - "Group pressure plays as a significant role to encourage group members to repay loans."

This study also provides two types of group pressure applying to default group members namely, ex-ante and ex-post. The ex-ante group pressures motivate the recipients of 
microfinance to repay the loans. Defaulter members will be given time to find another sources of fund to repay the loan. If an individual of the group members is unable to repay, the group may then employ ex-post such as seizure of assets. Seizure of assets occurs when an individual is unable to pay debt and the creditor may seize any movable or immoveable assets.

Group pressure as a social collateral component has also been considered by previous studies. These studies found that group members are willing to apply group pressure on a wilful defaulter and zero, otherwise (Feroze, Chauhan, Malhotra, and Kadlan 2011; Verhelle and Berlege, 2003). Armendariz and Morduch (2005) stated that group pressure plays a significant role in encouraging group members to repay their loan. Schurmann and Johnston (2009) claimed that the use of group lending approach and group pressure is to ensure success loan repayment by the microfinance recipients. It has been argued that group pressure is used as disciplinary and support mechanism within microcredit (Abbink, Irlenbusch and Renner, 2002). Phan (2008) reported that group pressure acts as an incentive to ensure loan repayment.

A body of the literature has examined the use of group pressure on loan repayment period (Besley and Coate, 1995; Siddiqi, 2008; Ajit and Rajeev, 2012). The findings in these studies reached to a consensus on the importance of group pressure on loan repayment period. For example: Ajit and Rajeev (2012) argued that group lending approach may use group pressure to encourage other members to repay the loans. Besley and Coate (1995) illustrated that social collateral through group pressure used repayment games to ensure timely payments among the group members. Rodriguez-Meza (2000) found that group pressure may allow faster loan recovery. The findings in these studies indicated that higher the group pressures often lead to higher loan recoveries. Furthermore, Siddiqi (2008) also stated that Grameen Bank adopted social collateral scheme through group pressure to ensure group members would make repayment in timely manner.

\section{Entrepreneurship Skills}

Most of the participants in this study agreed that entrepreneurship skill is an important component for the social collateral model of Islamic microfinance institutions. Entrepreneurship skills could be enhanced by assisting the microfinance recipients in enhancing their business skills. The participants opined: "One of the ways to improve the social collateral is by ensuring that these people have the necessary entrepreneurship skills in running their operations. We can help these people by ensuring that proper training is provided particularly in business skills. This will ensure that they will not be left behind."

Similar findings were also shown in Karlan and Valdivida (2010). Their study found that the goal of business training is to develop entrepreneurial skills. They noted that the aim of the business training is to improve basic business practices such as on how to use profits, how to treat clients, where to sell and produced goods and services. These improvements would lead to more sales, profits, more workers and as an incentive to join the formal sector. Of consequence, it improves the overall welfare for the clients. Therefore, the participants also proposed the development of entrepreneurship skills. They opined that: "Why not we follow the footstep of Chinese chambers of commerce? How they actually develop their business and how do they help each other? We should look at how social collateral enhances their capacity of financing and then compare Malaysian and Indian chambers of commerce."

This study also proposed that entrepreneurship skills should include basic skill, product development and marketing. Basic skill is necessary for small business to start a new 
business. Providing microcredit with training on entrepreneurship development and management may help to instil the mind sets and confidence of the microfinance recipients' ability to start and manage a new business (Tundui and Hawa, 2013; Alam and Molla, 2012; Alam, Hossain, and Zaman, 2011). Karlan, Harigaya, and Nadel (2006) examined the choice of microfinance mode in Peru that offers either credit with entrepreneurial skills or credit only. The findings of their study showed that clients who received training have increasing performance in sales and their business knowledge and skills although only in limited area. On the other hand, their result also showed high repayment rates among microfinance recipients who had received business training.

Kahandawaarachchi (2010) noted that Sri Lanka microfinance offers financial services as well as other services such as skills development to the poor. The aim of the skills development is to teach entrepreneurial skills that would improve the basic of business practices among microfinance recipients. For example: the microfinance institutions provide training to the poor on how to manage business and profit, how to budget the fund and where to sell. The improvements of the business skills may lead to increase sales and profits, more workers and knowledge needed to join formal sector (Karlan, Harigaya, and Nadel, 2006).

Kapoor and Sinha (2013) stated that product development plays an important role in increasing number of customers of any organizations. According to Brand (2001), the process of a product development starts with an idea for a new product and ends when they launched the new product. He further explained that the product development process consists of evaluating the new idea of the product, preparations for designing new product, and product testing before distribute to the market. The most important characteristic of successful product development is achieving speed to market.

Tran (2000) defined marketing as advertising and promoting products or services at selling price. Marketing also consists of the activities such as market segmentation, competitive analysis, and positioning strategy. Marketing is important to know about client, competitor and business environment. He further noted that entrepreneurs need to monitor and observe needs of their customers and market conditions to cope with environmental changes.

\section{Culture}

This study also found that culture plays an important role in determining the social collateral for Islamic microfinance. One of the participants mentioned - "Culture is a system of shared meaning held by members that distinguishes the organisation from other organisations. However, close relationship such as relatives has a negative impact on the prompt repayment as compared to mere acquaintance."

The finding in this study is consistent with previous studies. For example: Pellegrina and Scollo (2012) found microfinance recipients who have close relationship with the cosigner by way of kinship are less likely to default in repayment performance. This finding suggested that co-signers who are related with borrowers may have strong influence compared to other people. Leider et al. (2010, p.2) also argued that "co-signers are more likely to behave altruistically about their friend since own more information regarding their types and thus find it easier to enforce repayment". Similar findings were also reported in Gine and Karlan (2010) that suggested microfinance program should consider the importance of relationship between co-signer and microfinance recipients in order to maximise loan repayment rates. 
Yudomartono, Saefullah, Soemaryani and Mulyana (2012) stated that Kohls and Wederspahn have defined culture as "shared values of a society". It refers to the way of life group members that consists on how people thinking, says, shared belief and attitudes and language. It indicates that culture practices by people in agriculture areas are different with those who are live in coastal area. For example: the culture adopted by farmers is different to the culture adopted by the government officials, fisherman, and traders. Robbins, Judge, Odendaal and Roodt (2009) defined culture as an "institutional culture". Thus, the implementation of Rice Bank (Bank Lumbung), Village Bank (Bank Desa), and credit union institution (Lembaga Pengkreditan) should be adapted with its own culture (Yudomartono et al., 2012).

On the other hand, Dunford (2013) argued that microfinance recipients that have higher culture are more likely to make loan repayments on time and would be less likely to drop out of their groups. Gender also seems to have an impact on repayment culture (Hendricks, 2002-2003). D'Espallier, Bert, Guerin, Isabella and Mersland (2011) stated that women out do men in terms of loan repayment. For example: Armendariz and Morduch (2005) stated that the customers of Grameen Bank consists of men and women but due to the high default in loan repayment among men, the bank has decided to exclude men as its customers.

Pellegrina and Scollo (2012, p.5) stated that "kinship as a fundamental role in defining the intensity of the relationship". Hendricks (2000) conducted an exploratory study by focusing on the importance of culture on family and kinship in Ghana. One hundred and eight microfinance recipients were interviewed in his study in 1999. He found that the relationships such as family and kinship connections, social norms and values are considered to fall within the framework of informal institutions because they are not codified.

\section{Religiosity}

Finally, the participants agreed that the element of religiosity is an essential component that needs to be considered when it comes to Islamic microfinance. Generally, conventional microfinance institutions do not consider this as a component of social collateral. However, the responsibility to pay debt is highly important in Islam to the extent that when a borrower passed away, his next-of-kin has to pay his debt on his behalf. Regarding this issue, the participants viewed that "Elements of religiosity should be part of the microfinance in ensuring effective repayment of loan. There is no doubt that religion has been playing an important role in human life. Each religion implies a set of beliefs and specific moral rules to follow. Some of those rules and beliefs could be incorporated in everyday choices people make and may define their way of being and this includes microfinance."

Other studies in the literature have also focused on this issue. For example: Nawai and Shariff (2012) found that religious education affects microfinance recipients' loan repayment performance. Their result showed that microfinance recipients who received formal religious education were more responsible in repaying their loan. Al-Azzam, Hill, and Sarangi (2012) found that "individuals who are more religious are less likely to make late payment". This is because Islam emphasises that all Muslims should repay debt. Rulindo and Mardhatillah (2011) reported that being religious plays an important role in enhancing microentrepreneurs' economic performance. Said, Alam and Salwana (2015) also showed that being religious is associated with entrepreneurial activity and economic growth, especially for Islamic microfinance recipients. 


\section{CONCLUSIONS}

This study explores the components of social collateral in Islamic microfinance institutions. Similar to the conventional microfinance institution, the Islamic microfinance also considers social capital, group pressure, entrepreneurship skills, and culture as important components of social collateral. Based on the microfinance experiences in Malaysia, the participants noted that religiosity is also an important component of social collateral for the Islamic microfinance institution. Though it is not well known in the literature, the necessity of considering religiosity as social collateral is essential for Islamic microfinance since it is part of the Muslim life.

The findings in this study are based on the perspective of the Islamic microfinance only. Therefore, there may be a need to consider religiosity from the perspective of conventional microfinance.

\section{ENDNOTES}

* We would like to thank Accounting Research Institute (ARI), Universiti Teknologi MARA Malaysia, in collaboration with the Ministry of Higher Education Malaysia (MOHE) in providing the financial support for this research project.

${ }^{1}$ AIM is Malaysia's largest microcredit organisation. AIM has disbursed more than RM 2.3 billion in loans to 262,000 borrowers since its inception in 1987.

${ }^{2}$ PUNB is one of the most prominent entrepreneurship organizations in Malaysia. Since its inception in 1991, it has offers various entrepreneurship packages to assist entrepreneurs in small and medium size enterprises.

\section{REFERENCES}

Abbink, K., Irlenbusch, B., \& Renner, E. (2002). Group size and social ties in microfinance institutions. Working paper. University of Nottingham, United Kingdom, 22 November.

Ajit, D., \& Rajeev, C.B. (2012). Micro-finance and social capital: a study of microfinance institutions in Andhra Pradesh, India-2009. International Journal of Social Inquiry, 5(1-2), 67-84.

Alam, M. M., \& Molla, R. I. (2012). Inside Productivity of Microcredit in Bangladesh: A Surgical Analysis, Asian Economic and Financial Review, 2(3), 478-490.

Alam, M. M., \& Molla, R. I. (2012). The Limitations of Microcredit for Promoting Microenterprises in Bangladesh, Economic Annals, 57(192), 41-53.

Alam, M. M., Hossain, M. M., \& Zaman, F. (2011). Non-institutional Factors Affecting Microentrepreneurship Development in Bangladesh, International Review of Business Research Papers, 7(6), 240-247.

Al-Azzam, M., Hill, R. C., \& Sarangi, S. (2012). Repayment performance in group lending: evidence from Jordon. Journal of Development Economics, 97(2), 404-414.

Armendariz, B., \& Morduch, J. (2005). The Economics of Microfinance, MIT Press, Cambridge, MA.

Assadi, D. 2014. Le fonctionnement des groupes de prêts dans le contexte d'interdiction du taux d'intérêt : le cas de la microfinance marocaine, Cahiers du CEREN 45. Retrieved May 11, 2014 from http://documents.escdijon.eu/pdf/ceren/cahiers_45/CR45_1.pdf 
Besley, T., \& Coate, S. (1995). Group lending, repayment incentives and social collateral. Journal of Development Economics, 46 (1), 1-18.

Brand, M. (2001). The Microenterprise Best Practices (MBP) Guide to New Product Development. Working paper. U.S. Agency for International Development.

Brau, J. C., \& Woller, G. M. (2004). Microfinance: a comprehensive review of the existing literature. Journal of Enterpreneurial Finance and Business Ventures, 9 (1), 1-26.

Bryant, C. A. \& Norris, D. (2002). Measurement of social capital: the Canadian experience. International Conference on Social Capital Measurement in London, 25-27 September.

CALA (2013). CALA Social Capital Report, Retrieved February 29, 2013, from www.calasocialcapital.com.

Cassar, A., Crowley, L., \& Wydick, B. (2007). The effect of social capital on group loan repayment: evidence from field experiments. The Economic Journal, 117(517), 85-106.

Conning, J. (1996). Group lending, moral hazard, and the creation of social collateral. Working paper 195. University of Maryland, College Park.

D'Espallier, Bert, Guerin, Isabella, \& Mersland, R., (2011). Women and repayment in microfinance: a global analysis. World Development, 39(5), 758-772.

Dowla, A. (2006). In credit we trust: building social capital by Grameen Bank in Bangladesh. The Journal of Socio-Economics, 35(1), 102-122.

Dunford, C. (2013). Groups, social capital, microfinance and empowerment-a Tangled web. Retrieved May, 11, 2013 from microfinanceandworldhunger.org/.../groupssocial-capital-microfinance-

Eberhard, J. W. (2008). Attaining empowerment: the potential of religious social capital. Working paper. Georgia State University, Atlanta, GA, 28 December.

Eldblom, E., \& jarl, E. (2012). Can we trust the measurement of trust? working paper 219, Department of Economics, University of Lund, Sweden.

Feroze, S. M., Chauhan, A. K., Malhotra, R., \& Kadlan, K.S. (2011). Factors influencing group repayment performance in Haryana: application of Tobit model. Agriculture Economics Research Review, 24(1), 57-65.

Gine, X., \& Karlan, S. (2010). Group versus individual lending: long term evidence from Philippine microcredit lending groups. Working paper 61. Yale University, Department of Economics.

Gomez, R., \& Santor, E. (2001). Membership has its privileges: the effect of social capital and neighbourhood characteristics on the earnings of microfinance borrowers. Canadian Journal of Economics/Revue Canadienne d Economique, 34(4), 943-966.

Hendricks, L. (2000). Microfinance and culture: A case study in Ghana. Retrieved March 15, 2013, from http://hendricksandassociates.net/wpcontent/uploads/2010/03/final.pdf

Hendricks, L. (2002-2003). Microfinance, local culture, and development. Retrieved March 15, 2013, from http://www3.sympatico.ca/hendricks/devexmicrofinance.pdf

Hulme, M. K. \& Wright C. (2006). Internet based social lending: past, present and future. Social Future Observatory, (Oktober). Retrived from http://www.socialfuturesobservatory.co.uk/pdf_download/internetbasedsociallending.pdf

Kahandawaarachchi, T. (2010). Microfinance nurturing the enterpreneur spirit. Business Today, September.

Kapoor, S. \& Sinha, G. (2013). Factors influencing new product development in microfinance institutions: a perspective from North Indian Microfinance Institutions. Journal of Innovation Economic', 11(1), 83 - 105. 
Karlan, D., \& Valdivida, M. (2010). Can teaching business skills improve the impact of microcredit? working paper. Yale University, United States, US, 21 January.

Karlan, D., Harigaya, T., Nadel, S. (2006). Evaluating microfinance program innovation with randomized controlled trials: examples from business training and group versus individual liability. Working paper. Yale University, United States, US, 15 July.

Karlan, D., Mobius, M., Rosenblat, T., \& Szeidl, A. (2009). Trust and Social Collateral. The Quarterly Journal of Economics, 124(3), 1307-1361.

Kropp, J. D., Turvey, C. G., Just, D. R., Kong, R., \& Guo, P. (2009). Are the poor really more trustworthy? A micro-lending experiment. Agriculture Finance Review, 69(1), 67-87.

Kumar K, N. (2012). Dynamic incentives in microfinance group lending: an empirical analysis of progressive lending mechanism. SAGE Open, 2(2), 1-9.

Leider, S., Mobiuos, M., Rosenblat, T., \& Do, Q. (2010). What do we expect from our friends?" Journal of the European Economic Association, 8(1), 120-138.

Mahjabeen, R. (2008). Microfinancing in Bangladesh: impact on households, consumption and welfare. Journal of Policy Modeling, 30(6), 1083-1092.

Molla, R. I., \& Alam, M. M. 2011. Microcredit - A More Credible Social than Economic Program in Bangladesh, Economics Bulletin, 31(2), 1095-1104.

Morris, S. S., Woodworth, W. P., \& Hiatt, S. R. (2006). The value of networks in enterprise development: case studies in Eastern Europe and Southeast Asia. Journal of Developmental Entrepreneurship, 11(4), 345-356.

Nawai, N., \& Shariff, M. N. M. (2012). Factors affecting repayment performance in microfinance programs in Malaysia. Procedia - Social and Behavioral Sciences, 62(1), 806811.

Nielson, D. M. A. (2012). The supposed connection between group microfinance and social capital: a case study of the Peruvian microfinance market and social capital development. Working paper. Copenhagen of Business School, Denmark.

Nugroho, A. E., \& O'Hara, P. A. (2008). Microfinance sustainability and poverty outreach: a case study of microfinance and social capital in rural Java, Indonesia. Working paper. University of Technology GPO, Perth, Australia, 14 March.

Pellegrina, L. D. \& Scollo, A. (2012). Friends, family, and fools: co-signers and repayment rates in microcredit. Working paper. University of Milano-Bicocca, Milan, Italy, 4 December.

Phan, P. H. (2008). Enterpreneurship and microfinance a review and research agenda. Johns Hopkins University.

Putnam R. D. (1993). Social capital. Princeton University Press, United Kingdom, U.K, Making democracy work, (pp. 163-185).

Rinne, A. (2012). Lessons from microfinance for the sharing economy. Retrieved March, 8, 2013, from http://www.shareable.net/blog/lessons-from-microfinance-for-thesharing-economy

Robbins, S.P., Judge, T. A., Odendaal, A., \& Roodt, G. (2009), Organizational Behaviour: Global and Southern African perspectives, Pearson Education South Africa (Pty) Ltd., South African.

Rodriguez-Meza, J. L. (2000). Group and individual microcredit contracts: a dynamic numerical analysis. The Ohio State University, United State, US. Oxford.

Rotzer, G. (2007). The Blackwell Encyclopedia of Sociology, Blackwell Publishing, 
Rulindo, R. \& Mardhatillah, A. (2011). Spirituality, religiosity and economic performance of Muslim micro-entrepreneurs, paper presented at the International Conference on Islamic Foundation on Islamic Economic and Finance, 18-20 December, Doha, Qatar.

Said, J., Alam, M. M., \& Salwana, H. (2015). Performance of Islamic Microcredit in Terms of Maqasid Al-Shariah: Case Study on Amanah Ikhtiar Malaysia. Humanomics. 32(2).

Schurmann, A. T., \& Johnston, H. B. (2009). The group-lending model and social closure: microcredit, exclusion, and health in Bangladesh. Health Popul Nutr. 27(4), 518527.

Siddiqi, K. (2008). Potential of Islamic microfinance in Pakistan", Master Thesis submitted at the Markfield Institute of Higher Education in Association with the Loughborough University, UK.

Tran, N. H. (2000). Marketing in Microfinance Institutions. Innovations in microfinance. Technical Note No.2. Retrieved July 2, 2013 from http://pdf.usaid.gov/pdf_docs/PNACQ694.pdf

Tundui, C., \& Hawa, T. (2013). Microcredit, micro enterprising and repayment Myth: the case of micro and small women business entrepreneurs in Tanzania. American Journal of Business and Management, 2(1), 20-30.

United Nations World Summit Outcome Documents (2005). The General Assembly. 14-16 September 2005.

Verhelle, C., \& Berlage, L. (2003). Determinants of microfinance group performance: an empirical analysis of self-help groups in India. Working paper. Department of Economics, Katholic University Leuven, Belgium.

Woodworth, W. P. (2008). Reciporal dynamics: social capital and microcredit. ESR Review. 10 (2), 36-42.

World Bank (2009). What is social capital. Retrieved March 12, 2013, from http://web.worldbank.org/wbsite/external/topics/extsocialdevelopment/exttsocialcapital/0cont entmdk:20185164 menupk:418217 pagepk:148956 pipk:216618 thesitepk:401015,00.html

Yudomartono, H., Saefullah, K., Soemaryani, I., \& Mulyana, A., (2012). Building an inclusive microfinance model in poverty alleviation: integration between local culture and microfinance institutions. Working paper. Padjadjaran University, Sumedang, Indonesia, April, 2013. 